\title{
Characterization of Cystoisospora suis sexual stages in vitro
}

\author{
Anna Sophia Feix ${ }^{\dagger}$,Teresa Cruz-Bustos ${ }^{*}{ }^{\dagger}$, Bärbel Ruttkowski and Anja Joachim
}

\begin{abstract}
Background: The porcine coccidium Cystoisospora suis is characterized by a complex life-cycle during which asexual multiplication is followed by sexual development with two morphologically distinct cell types, the micro- and macrogametes. Genes related to the sexual stages and cell cycle progression were previously identified in related Apicomplexa. Dynein light chain type 1 and male gamete fusion factor HAP2 are restricted to microgametes. Tyrosine-rich proteins and oocyst wall proteins are a part of the oocyst wall. The Rad51/Dmc1-like protein and Nima-related protein kinases are associated with the cell cycle and fertilization process. Here, the sexual stages of $C$. suis were characterized in vitro morphologically and for temporal expression changes of the mentioned genes to gain insight into this poorly known phase of coccidian development.
\end{abstract}

Methods: Sexual stages of C. suis developing in vitro in porcine intestinal epithelial cells were examined by light and electron microscopy. The transcriptional levels of genes related to merozoite multiplication and sexual development were evaluated by quantitative real-time PCR at different time points of cultivation. Transcription levels were compared for parasites in culture supernatants at 6-9 days of cultivation (doc) and intracellular parasites at 6-15 doc.

Results: Sexual stage of $C$. suis was detected during 8-11 doc in vitro. Microgamonts ( $16.8 \pm 0.9 \mu \mathrm{m})$ and macrogamonts $(16.6 \pm 1.1 \mu \mathrm{m})$ are very similar in shape and size. Microgametes had a round body $(3.5 \pm 0.5 \mu \mathrm{m})$ and two flagella $(11.2 \pm 0.5 \mu \mathrm{m})$. Macrogametes were spherical with a diameter of $12.1 \pm 0.5 \mu \mathrm{m}$. Merozoite gene transcription peaked on $10 \mathrm{doc}$ and then declined. Genes related to the sexual stages and cell cycle showed an upregulation with a peak on 13 doc, after which they declined.

Conclusions: The present study linked gene expression changes to the detailed morphological description of $C$. suis sexual development in vitro, including fertilization, meiosis and oocyst formation in this unique model for coccidian parasites. Following this process at the cellular and molecular level will elucidate details on potential bottlenecks of $C$. suis development (applicable for coccidian parasites in general) which could be exploited as a novel target for control.

Keywords: Isospora suis, Gametes, DLC-1, HAP2, OWP, RAD51/Dmc, Nima-related protein kinases

\section{Background}

Cystoisospora suis (syn. Isospora suis Biester \& Murray, 1934) is a coccidian parasite of swine which causes diarrhea and reduced weight gain in suckling piglets, mostly in the first three weeks of life, and leads to unthriftiness

\footnotetext{
${ }^{*}$ Correspondence: Teresa.Cruz-Bustos@vetmeduni.ac.at

${ }^{\dagger}$ Anna Sophia Feix and Teresa Cruz-Bustos contributed equally to this work

Institute for Parasitology, Department of Pathobiology, University of Veterinary Medicine Vienna, Veterinaerplatz 1, Vienna 1210, Austria
}

at weaning, considerably impairing animal health and productivity [1-4]. As with all coccidian parasites, the life-cycle of $C$. suis is characterized by asexual multiplication (sporogony, merogony) followed by sexual development with two morphologically distinct cell types, the micro- and macrogametes which presumably fuse to form a zygote from which the oocyst arises $[5,6]$.

Previous studies have shown that the development of C. suis in vitro is comparable with the life-cycle in vivo; however, the development of sexual stages in vitro is 
delayed [7]. This makes it possible to observe, harvest and examine sexual stages in the short time frame in which they occur. Macrogametes of coccidians form without division and are large and immobile, while microgamonts divide several times to form microgametes, consisting of a small body and flagella which are used to move quickly in search of macrogametes [8].

After fertilization by a microgamete the wall-forming bodies of the macrogamete fuse and form the oocyst wall, as seen in other Coccidia $[9,10]$. In the coccidian parasite Eimeria two types of wall-forming bodies can be found, an electron dense form, giving rise to the outer layer of the oocyst, and sponge-like bodies that fuse to form the inner layer of the oocyst wall [9].

Transcriptomic and proteomic analyses carried out in Eimeria and Toxoplasma revealed different genes coding for proteins related to the sexual stages $[11,12]$. The two main protein families participating in oocyst wall formation in coccidia are tyrosine-rich proteins called GAM [13] and cysteine-rich proteins OWPs, first described in detail in Cryptosporidium [14, 15]. GAM proteins are found in the wall-forming bodies type 1 . Proteases break down GAM proteins into tyrosine-rich peptides, which are then oxidatively crosslinked by peroxidases and incorporated into the oocyst wall in dityrosine bonds $[16,17]$. GAM proteins are the most studied proteins of the oocyst wall; they were developed as antigens for transmission blocking vaccines targeting the gametocyte-specific proteins GAM56, GAM82 and GAM22 of Eimeria [13, 18-20]. Cysteine-rich OWPs have also been described in Toxoplasma gondii [21]. They are found in the wall-forming bodies type 2 . The cysteine residues form disulfide bridges responsible for the stabilization and formation of the oocyst and sporocyst walls, conferring additional strength and rigidity [22]. Proteins with important roles in apicomplexan male sexual stages are involved in axoneme and flagella assembly and construction [23], DNA replication [24], microgamete budding from microgamonts [25] and gamete fusion [26]. Upregulated expression of genes coding for tubulins, dyneins, radial spokes, basal body family proteins, a certain family protein, kinesins, enkurin-related protein, HAP2 and intraflagellar transport proteins was observed by RNA Seq analysis of Eimeria tenella sexual stages [27]. HAP2 is essential for the fusion of gametes surface membrane and subsequent fertilization [27], and it has been proposed as a possible candidate for a transmission blocking vaccine in apicomplexan parasites [28, 29].

The process of fertilization in Coccidia is still poorly understood and has not been visualized yet, but it is commonly assumed that, that following fusion of the microand macrogamete, the apicomplexan zygote develops into an unsporulated oocyst. The oocysts are excreted to the environment and the development continues, and meiosis and mitosis result in infectious haploid sporozoites [17, 30]. Among the genes thought to be involved in these processes are the meiotic recombination $\operatorname{Rad} 51$ and Dmc1, protein kinase, Aurora and Nima genes, Cyclin dependent kinase and Polo genes [15, 31, 32].

In this study we aimed to provide a first characterization of $C$. suis sexual stages in vitro by comparing the morphology of the stages and the transcriptional profiles of selected conserved genes related to the sexual development of apicomplexan parasites. We hypothesized (i) that all developmental stages of $C$. suis occur in vitro and are comparable to those in vivo experiments, although the in vitro development of the parasite takes longer compared to infections of piglets; and (ii) that during sexual development, transcription of genes related to this life-cycle phase is increased in C. suis similar to other Coccidia and Plasmodium.

\section{Methods \\ Cystoisospora suis oocyst collection}

Cystoisospora suis oocysts (strain Wien 1) were obtain from experimental infected suckling piglets. Piglets were raised with the sow in the animal facilities of the Institute of Parasitology, University of Veterinary Medicine Vienna, Austria. Infection of piglets, oocyst collection, oocyst isolation, oocyst purification and excystation were performed as described previously [7]. In deviation to the original protocol, after $\mathrm{NaOCl}$ treatment and washing, the oocysts were vortexed three times for $45 \mathrm{~s}$ with Precellys ${ }^{\circledR}$ glass beads (Peqlab, Erlangen, Germany) in $2 \%$ sodium taurocholate hydrate (Sigma-Aldrich, St. Louis, USA) in DMEM/Ham's F-12 culture medium (Gibco, Thermo Fisher Scientific, Waltham, USA).

\section{In vitro culture and parasite harvest}

Intestinal porcine epithelial cells (IPEC-1, ACC 705, Leibniz Institute DSMZ-German Collection of Microorganisms and Cell Cultures $\mathrm{GmbH}$, Leibniz, Germany) [33-35] were used as host cells in vitro (seeded $4 \times 10^{5}$ per well in a 6-well plate), in a DMEM/Ham's F-12 medium (Gibco) with 5\% fetal calf serum (FCS, Gibco) and $100 \mathrm{U} / \mathrm{ml}$ penicillin and $0.1 \mathrm{mg} / \mathrm{ml}$ streptomycin (PAA, Pasching, Austria) at $37{ }^{\circ} \mathrm{C}$ in $5 \% \mathrm{CO}_{2}$. After $24 \mathrm{~h}$ of cell growth IPEC-1 were infected with $5 \times 10^{3}$ sporozoites released from excysted oocysts and incubated further at $40{ }^{\circ} \mathrm{C}$. Free sexual stages were harvested by collecting culture medium supernatant daily at 9-11 days of cultivation (doc). The collected stages were washed with phosphate-buffered saline (PBS; Gibco; $144.0 \mathrm{mg} / \mathrm{K} \mathrm{K}_{2} \mathrm{PO}_{4}$, $9000.0 \mathrm{mg} / \mathrm{l} \mathrm{NaCl}, 795.0 \mathrm{mg} / 1 \mathrm{Na}_{2} \mathrm{HPO}_{4}-7 \mathrm{H}_{2} \mathrm{O}$ ) and purified using a Percoll ${ }^{\circledR}$ (GE Healthcare, Uppsala, Sweden) density gradient with layers at $80 \%, 40 \%$ and $30 \%$, and the 
sample on top. The gradient was centrifuged at $600 \times g$ for $10 \mathrm{~min}$ at $20{ }^{\circ} \mathrm{C}$ in a Mega Star $3.0 \mathrm{R}$ swing bucket centrifuge (VWR International, Leuven, Belgium). Both acceleration and deceleration were at the lowest possible setting. For the sampling of intracellular sexual stages, adhering host cells and parasites were incubated with Accutase $^{\circledR}$ (Thermo Fisher Scientific, Waltham, USA) for $30 \mathrm{~min}$ and the detached material was washed twice with PBS and pelleted by centrifugation at $600 \times g$ for $10 \mathrm{~min}$. The numbers of sexual stages were estimated in the cell culture chambers and counted in a Neubauer-counting chamber at each given time point, and the mean numbers of sexual stages per well were calculated.

\section{Light and electron microscopy}

Digital microphotographs of all in vitro C. suis stages, but especially isolated sexual stages, both live and fixed in $100 \% \mathrm{EtOH}$, were taken with an Olympus IX71 inverse microscope (Olympus, Shinjuku, Japan) or a Zeiss Imager Z2 microscope (Zeiss, Jena, Germany) at $400 \times$ and $600 \times$ magnification and measured $(n=50$ per stage) with Zeiss ZEN lite software (Zeiss).

For scanning electron microscopy sample preparation coverslips were washed in $100 \% \mathrm{EtOH}$ and coated with $0.1 \%$ poly-D-lysine (Merck Millipore, Burlington, USA) on which the isolated sexual stages were left to settle for $1 \mathrm{~h}$ at $36^{\circ} \mathrm{C}$ in PBS. Afterwards the parasites were fixed for $3 \mathrm{~min}$ on the cover slip using $2.5 \%$ glutaraldehyde in PBS. The samples were washed twice in PBS for 15 min. Post-fixation was performed with $1 \%$ osmium tetroxide for $3 \mathrm{~min}$. The coverslips were dehydrated in an ascending alcohol series from $30-100 \%$ ethanol for $3 \mathrm{~min}$ each. Thereafter the samples were critical point dried in a Leica CPD 300 (Leica Microsystems, Wetzlar, Deutschland). The dried samples were mounted on metal stubs and gold sputtered for $80 \mathrm{~s}$ with a JEOL JFC2300HR (JEOL GmbH, Freising, Germany). All scanning electron microscopy work was performed at the Core Facility Cell Imaging and Ultrastructure Research, University of Vienna-member of the Vienna Life-Science Instruments (VLSI). Sexual stages were photographed with a JEOL IT 300 scanning electron microscope (JEOL) and measured with Zeiss ZEN lite software (Zeiss).

\section{Transcription levels at different time points of $C$. suis development in vitro}

Quantitative real-time PCR (qPCR) was used to quantify the transcripts levels of four genes related to sexual stages, four genes related to cellular division and meiosis and one related to the merozoite stage of $C$. suis at different time points of development in vitro.

Total RNA was isolated from infected cell cultures using an RNeasy $^{\circledR}$ mini kit (Qiagen, Hilden, Germany) and treated with RNase-free DNase (Qiagen) according to the manufacturer's instructions to remove any DNA contamination. Total RNA was quantified using a NanoDrop $^{\circledR} 2000$ (Thermo Fischer Scientific, Waltham, MA, USA). cDNA synthesis was accomplished using the iScript cDNA synthesis kit (Bio-Rad, Hercules, California, USA).

The nucleotides sequences for genes linked with sexual development in Apicomplexa (Table 1) were searched using the Basic Search Alignment Tool (BLAST) in the genomic resource database ToxoDB (https://toxodb.org/ toxo/). Alignment analysis and calculation of percentage identity were performed using Clustal omega (https:// www.ebi.ac.uk/Tools/msa/clustalo).

Transcription levels were assessed daily from 6-15 doc. Quantitative PCR amplification of cDNA was carried

Table 1 Primers used in this study

\begin{tabular}{|c|c|c|}
\hline & Primer & Sequence $\left(5^{\prime}-3^{\prime}\right)$ \\
\hline 1 & FW-ACTIN & CTTGCTGGCCGTGATTTGAC \\
\hline 2 & Rv-ACTIN & ATATTGCCGTCCGGAAGCTC \\
\hline 3 & Probe-ACTIN & CCTCCGCCGAGAAGGAAATT \\
\hline 4 & FW-GAPDH & TTCAACGAGAAGGAGCCAAG \\
\hline 5 & Rv-GAPDH & CTTCGGAGGTGCAGACATG \\
\hline 6 & Probe-GAPDH & CAAGGAAAAGGCTGAGGCGCAT \\
\hline 7 & FW-HAP2 & GGAACCCAGGGAAATTTTGT \\
\hline 8 & Rv-HAP2 & CATGTTGTTGATGTGCGTGA \\
\hline 9 & Probe-HAP2 & GCTGCTGGTGCAGTGAGGTC \\
\hline 10 & Fw-DLC1 & TGCTATGGCCTGTTGATATGC \\
\hline 11 & Rv-DLC1 & CTTCTGGTCGAGCTCCTTTT \\
\hline 12 & Probe-DLC1 & TGCTGCGCGTGACTGTATAATCCA \\
\hline 13 & FW-OWP1 & CCAGAAGGATGTTTATTTGCCG \\
\hline 14 & Rv-OWP1 & TGGGCAGATGTATTCAGGTTC \\
\hline 15 & Probe-OWP1 & AATCCGAAGGGCAGCGTTGTAGAA \\
\hline 16 & Fw-TyRP & GAACTGGACGGTGATCGTGA \\
\hline 17 & Rv-TyRP & GCTCTCAATAAGTCCCTCAGAG \\
\hline 18 & Probe-TyRP & CTCATGCGCTCGCTACCTGA \\
\hline 19 & Fw-Rad51 & GCTTCGCTTTGCTTATTGTC \\
\hline 20 & Rv-Rad51 & CAACAACAGCCACACCATAC \\
\hline 21 & Probe-Rad51 & TGCCACGGCCCTATACAGGT \\
\hline 22 & FW-NIMA1 & GCTGGAAACTGGTGTTTTAC \\
\hline 23 & RV-NIMA1 & GCATCGCAGTACTCCATAAC \\
\hline 24 & Probe-NIMA1 & GTGAACTTCGGCACCCCAAC \\
\hline 25 & FW-NIMA2 & AGGACAACTACATCCGTGTC \\
\hline 26 & Rv-NIMA2 & CGTGACATATATTTCGCTGA \\
\hline 27 & Probe-NIMA2 & TCCAGCAAGCAAGAACGCAG \\
\hline 28 & FW-NIMA4 & AAAGAGTCGCAGATTCTCAG \\
\hline 29 & Rv-NIMA4 & CCTGCGTATGATCAAGAAGT \\
\hline 30 & Probe-NIMA4 & AGAATTCGCCTGGCGGATTT \\
\hline 31 & Fw-CSUI_005805 & CCTGAAAGTCGCCTGTCCAT \\
\hline 32 & Rv-CSUI_005805 & GACGCGTCAGCCGTTATAGT \\
\hline 33 & Probe-CSUI_005805 & CTCTCAGTTTCGCGGCACCT \\
\hline
\end{tabular}


out on a Mx3000P thermal cycler (Agilent Technologies, Santa Clara, CA, USA). The primers for gene amplification are listed in Table 1. Reaction mixtures contained $2.5 \mu \mathrm{l}$ of sample DNA $(100 \mathrm{ng} / \mu \mathrm{l}), 5 \mu \mathrm{l}$ of SsoAdvanced $^{\mathrm{TM}}$ Universal Probes Supermix (Bio-Rad) and $1.3 \mu$ l of nuclease-free water with primers and probes at a final concentration of 500 and $200 \mathrm{nM}$, respectively. Activation of polymerase was performed at $95{ }^{\circ} \mathrm{C}$ for $2 \mathrm{~min}$, followed by 50 cycles of $95{ }^{\circ} \mathrm{C}$ for $15 \mathrm{~s}$ and $60{ }^{\circ} \mathrm{C}$ for $30 \mathrm{~s}$. Each sample was run in triplicate and the complete experiment was performed in two separate biological replicates. The qPCR results were normalized against each of the two reference genes, namely glyceraldehyde-3-phosphate and actin. Average gene expression relative to the endogenous control for each sample was calculated using the $2^{-\Delta \Delta C q}$ method.

\section{Statistical analysis}

All values are expressed as means \pm standard error of the mean (SEM). Significant differences among groups were compared using the Student's t-test or one-way ANOVA with multiple comparisons. Differences were considered statistically significant at $P<0.05$. All statistical analyses were conducted using GraphPad $^{\circledR}$ Prism 8.2 (GraphPad Software, San Diego, CA).

\section{Results and discussion Morphology}

Sporozoite-infected cell cultures are a suitable model for producing all stages of $C$. suis in vitro. Free merozoites were detected in appreciable numbers from day 6 doc. Sexual stages occured in appreciable numbers between 8-11 doc and were mainly found outside the host cell. Early sexual stages were first detected at 8 doc. First gamonts could be located from 9 doc onwards, whereas first macrogametes and motile microgametes could be found a day later (Fig. 1). We estimated that the ratio of gamonts:early sexual stages was about 1:2. The first oocysts appeared 11 doc until 13 doc.

The sexual development of coccidians, including $C$. suis, is not well characterized [8]. Although it is presumed that sexual stages are crucial in parasite development, little is known about their morphology, especially in vitro [6]. As the life-cycle of $C$. suis takes longer in vitro (about 11 days) than in vivo (5 days) [4], it is possible to collect samples of every stage of $C$. suis development, hence making sexual stages available for further research.

Early sexual stages (immature gamonts) varied in form and size but their length was on average $15.6 \pm 0.5 \mu \mathrm{m}$ $(n=50)$ and their width $11.6 \pm 0.4 \mu \mathrm{m}(n=50$, Fig. 2a). Both micro- and macrogamonts were subspherical and had very similar diameter, however microgamonts were on average $16.8 \pm 0.9 \mu \mathrm{m}(n=50)$, whereas macrogamonts were $16.6 \pm 1.1(n=50)$ in average diameter (Table 2). In light microscopy, unstained microgamonts were recognized by their large vacuole and motile microgametes inside (Fig. 2b, c). Both micro- and macrogamonts were often found in close proximity to each other (Fig. 2b, d, Additional file 1), and the egress of microgametes from microgamonts could be observed during a 4-hour time frame. Each microgamont contained between 30-40 microgametes.

Scanning electron microscopy observations showed that microgametes consisted of a small, spherical $(3.5 \pm 0.5 \mu \mathrm{m}, n=50)$ body with two opposing flagella, $11.2 \pm 0.5 \mu \mathrm{m}$ in length $(n=50$, Fig. $3 \mathrm{a})$, which enabled the quick movement of the microgamete in search for

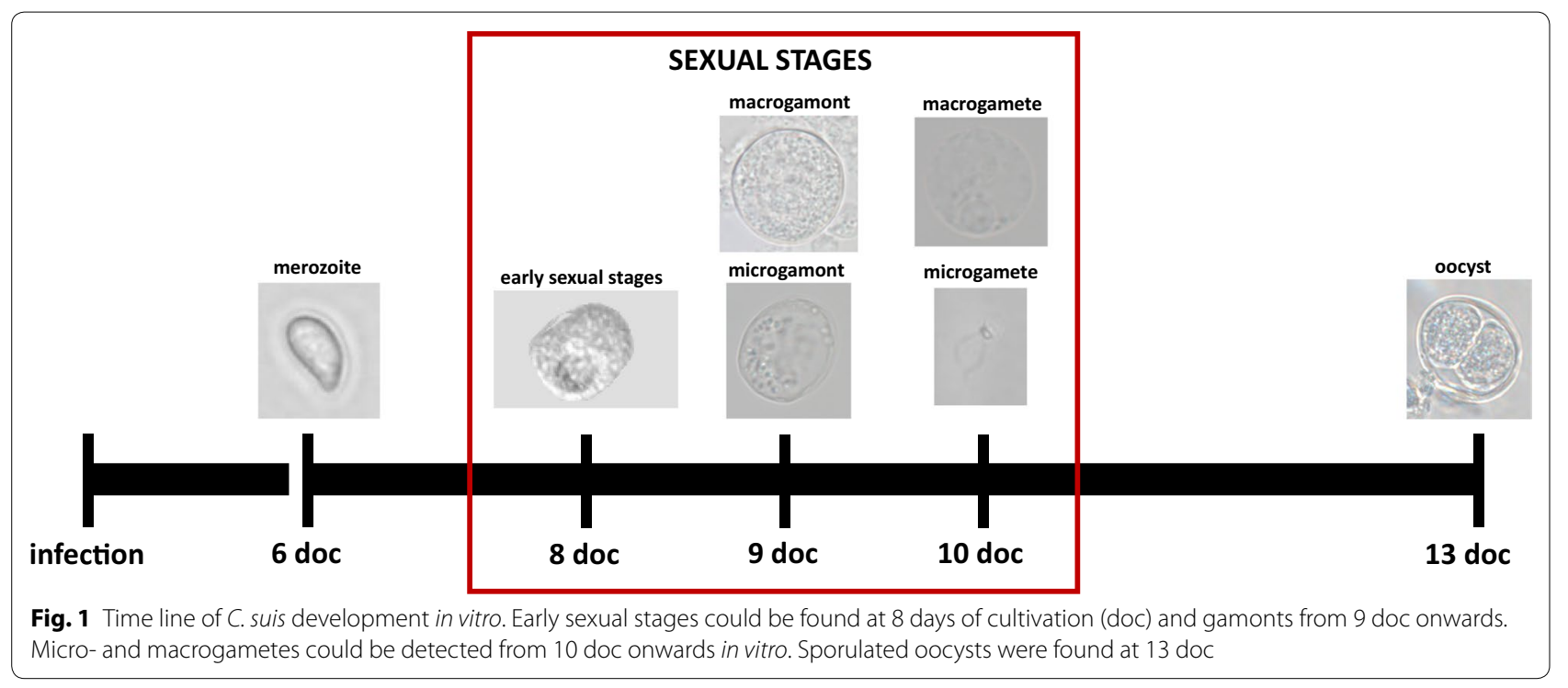



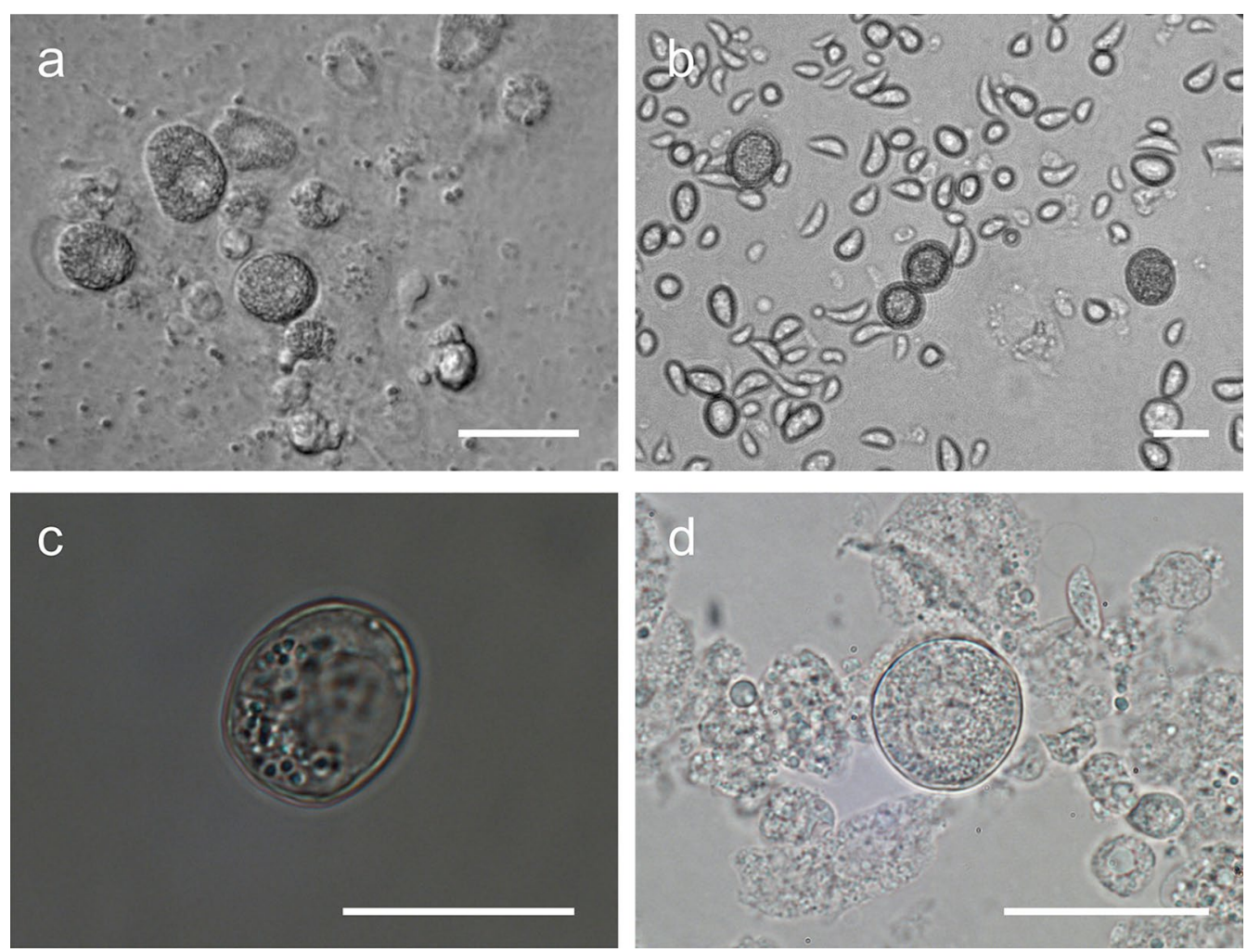

Fig. 2 Light microscopy of different sexual stages of C. suis in vitro culture. a Early sexual stages, 7 days of cultivation (doc), differential interference contrast. b Micro- and macrogamont in close proximity to each other, 8 doc, differential interference contrast. c Microgamont, 8 doc. d Macrogamont, 8 doc. Scale-bars: $20 \mu \mathrm{m}$

Table 2 Overview of mean, standard deviation, variance and range of $C$. suis sexual stages in vitro $(n=50)$

\begin{tabular}{|c|c|c|c|c|c|c|c|}
\hline & \multicolumn{2}{|c|}{ Early sexual stages } & \multirow{2}{*}{$\begin{array}{l}\text { Microgamonts } \\
\text { Diameter }\end{array}$} & \multirow{2}{*}{$\begin{array}{l}\text { Macrogamonts } \\
\text { Diameter }\end{array}$} & \multicolumn{2}{|c|}{ Microgametes } & \multirow{2}{*}{$\begin{array}{l}\text { Macrogamets } \\
\text { Diameter }\end{array}$} \\
\hline & Width & Length & & & Body & Tail & \\
\hline Mean & 11.6 & 15.6 & 16.8 & 16.6 & 3.5 & 11.2 & 12.1 \\
\hline Standard deviation & 0.4 & 0.5 & 0.9 & 1.1 & 0.5 & 0.5 & 0.5 \\
\hline Variance & 0.2 & 0.2 & 0.9 & 1.3 & 0.3 & 0.3 & 0.2 \\
\hline Minimum & 11.0 & 15.0 & 15.4 & 15.1 & 3.0 & 10.8 & 11.5 \\
\hline Maximum & 12.5 & 16.5 & 18.4 & 18.4 & 5.0 & 12.3 & 13.0 \\
\hline
\end{tabular}

Note: All measurements are in micrometers

a macrogamete. Macrogametes on the other hand were immobile, spherical with a smooth surface and had a diameter of $12.1 \pm 0.5 \mu \mathrm{m}(n=50$; Fig. 3b, Table 2$)$.

To our knowledge, this study provides the first detailed in vitro characterization of sexual stages of $C$. suis. Previous in vivo studies already described immature micro- and macrogamonts in tissue sections of the small intestine $[5,36]$. Early sexual stages are described as ovoid to elongate and smaller in size than those in vitro (immature microgamonts: $11.8 \times 8.4 \mu \mathrm{m}$; immature macrogamonts: $9.4 \times 6.5 \mu \mathrm{m}$ ) while the shape and size of mature micro- and macrogamonts are comparable to those in the early sexual stages [6]. Other closely related coccidian species show similar morphology of the sexual stages [37, 38]; however, microgametes of T. gondii and Eimeria [17] have flagella on the posterior end, whereas in C. suis they are clearly positioned on opposite sides, which might also affect microgamete movement on the search for a macrogamete. With an in vitro system that 

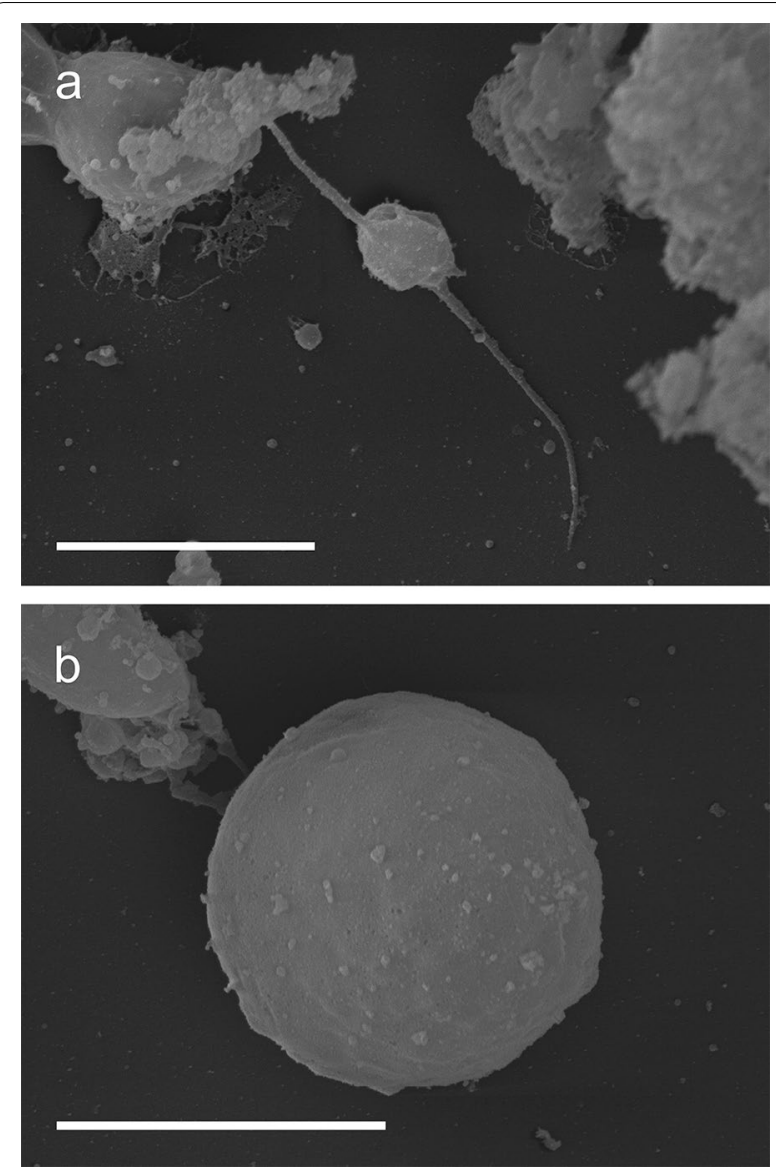

Fig. 3 Scanning electron microscopy of adult sexual stages of $C$. suis in vitro culture. a Microgamete, 10 days of cultivation (doc). $\mathbf{b}$ Macrogamete from 10 doc. Scale-bars: 5 m

allows for the collection and examination of mature sexual stages of $C$. suis, further studies on their properties and the fertilization process in Coccidia will be possible.

\section{Genes linked to sexual stages}

Identification of genes linked to the sexual stages is crucial to understand the developmental biology and the fertilization process of organisms with sexual development, including apicomplexan protozoans. Here, we analyzed eight of the genes with highest upregulated transcripts in microgametes, macrogametes and oocysts based on previous studies in Apicomplexa [11, 12, 27, 29, 31, 3942]. To identify genes or their orthologues related to the sexual development in C. suis, we used the ToxoDB parasite database and determined four genes related to sexual stages and four genes related to meiosis and cellular division (see Table 1).

For microgametes, the orthologues of dynein light chain 1 (DLC1) and the male gamete fusion factor (HAP2), CsDLC1 (CSUI_000751) and CsHAP2 (CSUI_000472), clustered with the respective genes from closely related coccidian parasites. Sequence analyses revealed identities greater than $60 \%$ with $T$. gondii and Neospora caninum, signifying the close relationship of $C$. suis with these two species [42], and more than $36 \%$ with Eimeria necatrix (Table 1).

Two of the most highly transcribed genes found in macrogametes code for proteins involved in the formation of the oocyst wall. CsOWP1 (CSUI_006207) has more than $65 \%$ of identity with that of T. gondii (Table 1 ). Genome analysis of C. suis and T. gondii failed to identify orthologues for the GAM56 protein of Eimeria but revealed three low molecular weight hypothetical proteins possessing both a leader peptide and tyrosine-rich sequences. CSUI_001473 is an orthologue with 54\% of homology with a gene coding for a tyrosine rich protein in Toxoplasma (TGME49_037080). Two of these three genes (TGME49_037080 and TGME49_087250) have peak expression levels in oocysts and the encoded proteins are incorporated as a part of the oocyst wall [40].

Table 3 Classification of genes used in this study from C. suis and their comparison with other coccidian parasites

\begin{tabular}{|c|c|c|c|c|c|c|c|}
\hline & \multirow{2}{*}{$\begin{array}{l}\text { Cystoisospora suis } \\
\text { Accession no. }\end{array}$} & \multicolumn{2}{|l|}{ Toxoplasma gondii } & \multicolumn{2}{|l|}{ Eimeria necatrix } & \multicolumn{2}{|c|}{ Neospora caninum } \\
\hline & & Accession no. & Identity (\%) & Accession no. & Identity (\%) & Accession no. & Identity (\%) \\
\hline Dynein light chain type 1 (DLC1) & CSUI_000751 & TGARI_244900 & 71.70 & ENH_00055140 & 36.49 & NCLIV_019360 & 74.53 \\
\hline Male gamete fusion factor (HAP2) & CSUI_000472 & TGARI_285940 & 63.80 & ENH_00067440 & 37.5 & NCLIV_014480 & 61.28 \\
\hline Oocyst Wall protein (OWP1) & CSUI_006207 & TGARI_204420 & 65.87 & ENH_00062180 & 23.45 & NCLIV_020820 & 66.87 \\
\hline Tyrosine rich, "Eimeria gam-like" & CSUI_001473 & TGARI_237080 & 54.97 & ENH_00047090 & 22.52 & NCLIV_050960 & 48.83 \\
\hline DNA repair proteinRad51/dmc1-like & CSUI_004539 & TGARI_272900 & 93.18 & ENH_00059490 & 81.98 & NCLIV_059840 & 46.23 \\
\hline Nima-related protein kinase 1 Nima 1 & CSUI_004317 & $\begin{array}{l}\text { TGARI_292140A; } \\
\text { TGARI_292140B }\end{array}$ & 43.97 & ENH_00060280 & 46.41 & NCLIV_043340 & 42.44 \\
\hline Nima-related protein kinase 2 Nima2 & CSUI_003099 & TGARI_307640 & 86.62 & ENH_00076430 & 65.94 & & \\
\hline Nima-related protein kinase 4 Nima4 & CSUI_000744 & TGARI_244620 & 77.14 & ENH_00003390 & 31.27 & NCLIV_019170 & 83.46 \\
\hline
\end{tabular}

Notes: Percentage values represent identities of Toxoplasma, Eimeria and Neospora genes with their corresponding Cystoisospora orthologs. All sequences are found in the genomic resource database ToxoDB (https://toxodb.org/toxo/). Alignment analyses were performed using the Clustal omega (https://www.ebi.ac.uk/Tools/msa/ clustalo) 
Among the genes with high expression in oocysts of Toxoplasma and Cryptosporidium [15, 40] we determined one coding for the meiotic recombination Rad51/ Dmc1-like protein, and the orthologue in C. suis, CSUI_004539, had a 93\% similarity to the gene of Toxoplasma (TGARI_272900) (Table 3).

Protein kinases have a role not only for signalling, but also during the transition states of cells [43]. Nima ("never in mitosis-gene A")-related kinases of Plasmodium and Toxoplasma are involved in post-fertilization processes and in the meiosis [32]. We found three orthologues for Nima genes, one of them specific for male gametocytes, Nima1 (CSUI_004317) and two of them for female gametocytes, Nima2 and Nima4, (CSUI_003099 and CSUI_000744) and all three showed more than $40 \%$ of homology with the respective genes of Toxoplasma (Table 3).

The expression profiles of one gene related to asexual stages (merozoites) of C. suis (CSUI_005805 [44]), the four genes related to sexual stages and the four genes related to cellular division and meiosis were examined at different time points of cultivation in vitro in extracellular and intracellular parasites.

To evaluate the development of merozoites during cultivation and to test the suitability of the qPCR analysis for the detection of temporal changes in gene transcription, we included the uncharacterized merozoite-specific gene CSUI_005805. The level of the transcription for merozoites increased until it reached the maximum around 9-10 doc and then declined (Fig. 4). In previous studies, this gene showed a higher transcription in merozoites compared to sporozoites and in the present study, it showed higher levels during merozoite development compared to sexual development and oocyst formation. The transcriptional level increased throughout the entire merogony, indicating that this protein might be important for the establishment and/or growth of merozoites inside the host cell [44].

Transcript levels of genes related to sexual development in extracellular parasites were compared with 6 doc as a reference for merozoites released into the medium and 9-10 doc for extracellular gamonts/gametes. The transcription levels were 8-9-fold higher in gamonts/ gametes compared to merozoites (Fig. 5a), which agrees with the high level of upregulation demonstrated in RNA-seq analysis of sexual stages of Eimeria spp. [11].

Transcription levels of intracellular parasites were compared daily at 6-15 doc. As a reference point, we used day 10 because on that day first mature gametes were seen in vitro. The microgamete-related genes transcripts reach peaks on 13-14 doc and the increase was 10-90-fold higher compared to merozoites at 6 doc (Fig. 6) which is in agreement with results for RNA seq comparing merozoites from third-generation
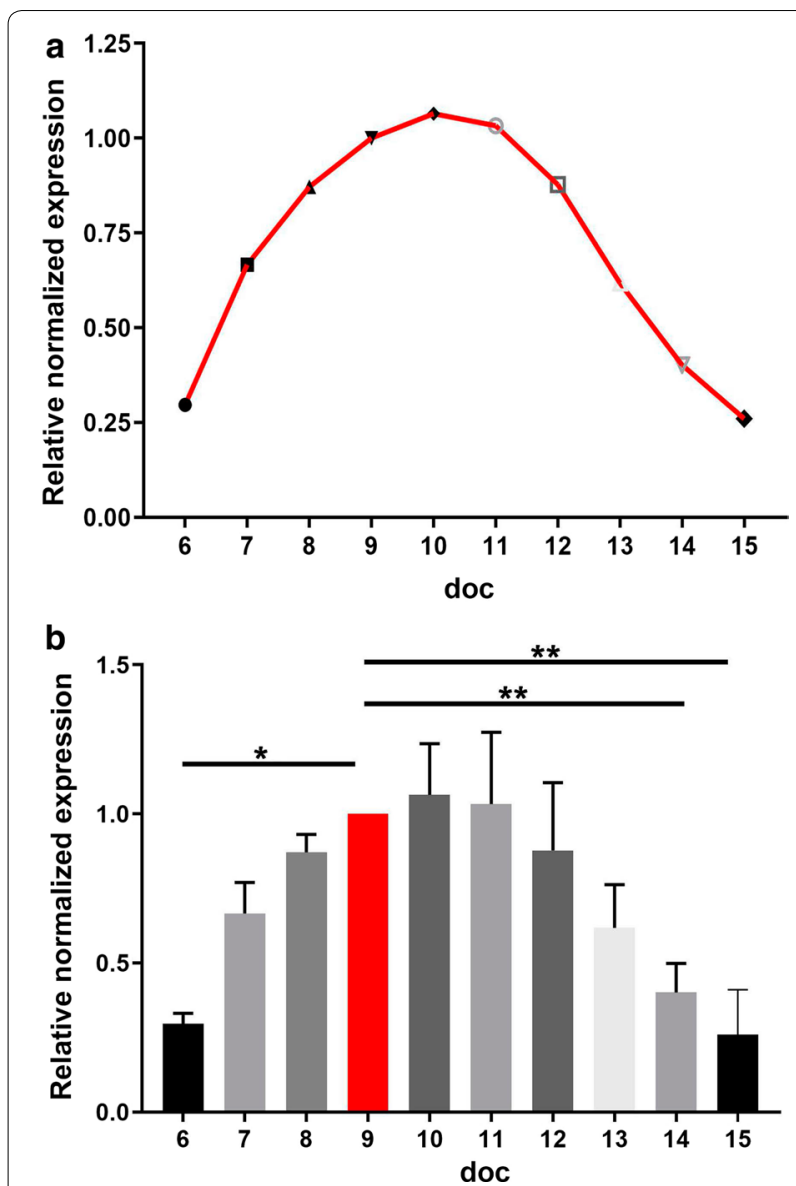

Fig. 4 Relative mRNA expression levels of CSUI_005805 in intracellular parasites. Qualitative RT-PCR of intracellular parasites from 6-15 days of cultivation (doc). Values represent the mean \pm standard error (SE) $(n=4)$. One-way ANOVA with multiple comparisons. ${ }^{* *} P<0.01$. For details on statistical tests see Additional file 2: Table $\mathrm{S1}$

merozoites and gamonts of Eimeria [11]. The levels for DLC1 and HAP2 (Fig. 6a, c, d) transcripts on 13 and 14 doc were 30 -fold and 60-fold higher, respectively, compared to day 6 with no detectable expression. Dynein proteins are part of the flagellum of microgametes and form part of the microtubule motor [45]. They are also involved in mitosis and meiosis, and are the major constituents of mitotic spindles, which are used to pull eukaryotic chromosomes apart [46]. As judged from the gene upregulation, these processes take place in $C$. suis in vitro between 9-15 doc. However, before that time point no transcription of DLC1 could be measured and the expression of DLC1 in Apicomplexa seems to be restricted to microgametes as described earlier [11].

In addition, we observed an upregulation of the gene expression of the fusogen HAP2 during 9-13 doc followed by a decrease (Fig. 6a, d). Its expression is also 

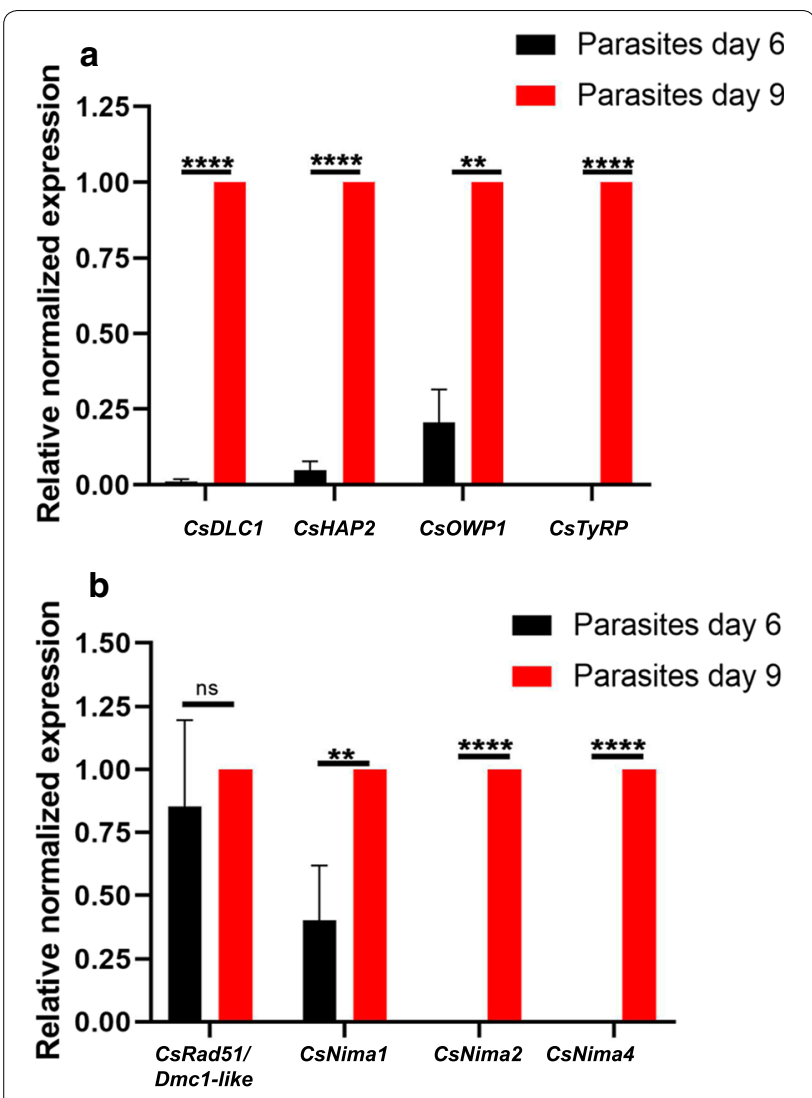

Fig. 5 Relative mRNA expression levels of sexual related genes, cellular division and meiosis genes in extracellular parasites. Qualitative RT-PCR of intracellular parasites 6 to and 9 days of cultivation (doc). Values represent the mean \pm standard error (SE) $(n=4)$. Unpaired Student's t-test: ns: not significant $(P>0.05)$,

${ }^{*} P<0.01,{ }^{* * *} P<0.0001$. For details on statistical tests see Additional file 2: Table $\mathrm{S1}$

restricted to male gametes and its function in gamete fusion and during fertilization is extensively described for plants and unicellular eukaryotes [26, 47]. The results in C. suis correlate with previous reports on Eimeria and Toxoplasma. HAP2 is found in microgametes and unsporulated oocysts but not in sporulated oocysts or sporozoites [26, 27, 40, 48, 49]. Moreover, transcription of $H A P 2$ was increased during the enteric development of T. gondii in the intestine of cats. HAP2 knockout parasites failed to fertilize and produce oocysts in vivo, and this supports the hypothesis that interfering with the fertilization process can be utilized in a transmission-blocking vaccine [29]. As for $D L C 1$, expression seems to be restricted to microgametes.

Oocyst wall formation is a hallmark of coccidian development, and $O W P$ and GAM-encoded proteins have previously been characterized in Eimeria and Toxoplasma as well as Cryptosporidium as constituents of the oocyst wall $[29,50,51]$.
The GAM proteins EmGam56 and EmGam82 were identified as antigens that conferred protection against different species of chicken Eimeria due to their conserved nature. A subunit vaccine for immunization was previously developed from E. maxima gamont proteins and commercialized for the prevention of coccidiosis $[9,52]$.

No homologues for GAM genes were found in the C. suis genome or in the Toxoplasma database. However, oocysts of $C$. suis display the characteristic autofluorescence similar to other coccidia $[17,53]$ which is likely due to the dityrosine bonds formed between tyrosine-rich proteins present in the oocyst wall [11, 51]. A search in the proteome of Toxoplasma for predicted proteins with sequences rich in tyrosine identified five hypothetical proteins, and three of them presented highest levels of expression in the oocyst wall proteomic fraction [31] and were upregulated in oocyst transcriptomes compared to tachyzoites and bradyzoites [40]. We identified and analyzed an orthologue of one of them, TyRP. Gene transcripts of both proteins presumably involved in oocyst wall formation, OWP1 and $T y R P$, were upregulated until $13 \mathrm{doc}$ and then steeply declined (Fig. 6b, e, f). While $T y R P$ transcription could only be detected from 8 doc (Fig. Fig. 6b, f), low transcription levels for OWP1 were already found from 6 doc (Fig. 6b, e). indicating that merozoites present at this time point are probably already committed to a further development into macrogamonts, as described for E. tenella [17, 27].

In extracellular parasites, the RNA transcription of Rad51/Dmc1-like showed similar levels of transcription in parasites from 6 and 9-10 doc (Fig. 5b). In intracellular stages of C. suis, the RNA transcription levels of Rad51/ Dmc1-like were rather constant from 6-12 doc except for an increase 13-14 doc (Fig. 7a, c) which probably corresponds to meiosis during the formation of the oocyst, since the RAD51/Dmc1-like gene codes for a protein of the Rad51 family which assists in repair of DNA double strand breaks during mitosis, while the two recombinases, Rad51 and Dmc1, facilitate the recombination between homologous chromosomes during meiosis [54].

Nima-related kinases (Nek or NRK) represent a conserved family of serine/threonine kinases implicated in the regulation of distinct cellular events [47]. Neks have important roles in the maintenance of centrosome function and structure, mitotic microtubule organization, and the regulation of axonemal microtubule in cilia and flagella. Nima1 is an orthologue of Nek2 in humans which is involved in the maintenance of centrosome structures and mitotic microtubule organization, thus playing a role during mitosis. In Toxoplasma, Nima1 is essential for centrosome splitting, proper formation of daughter cell 

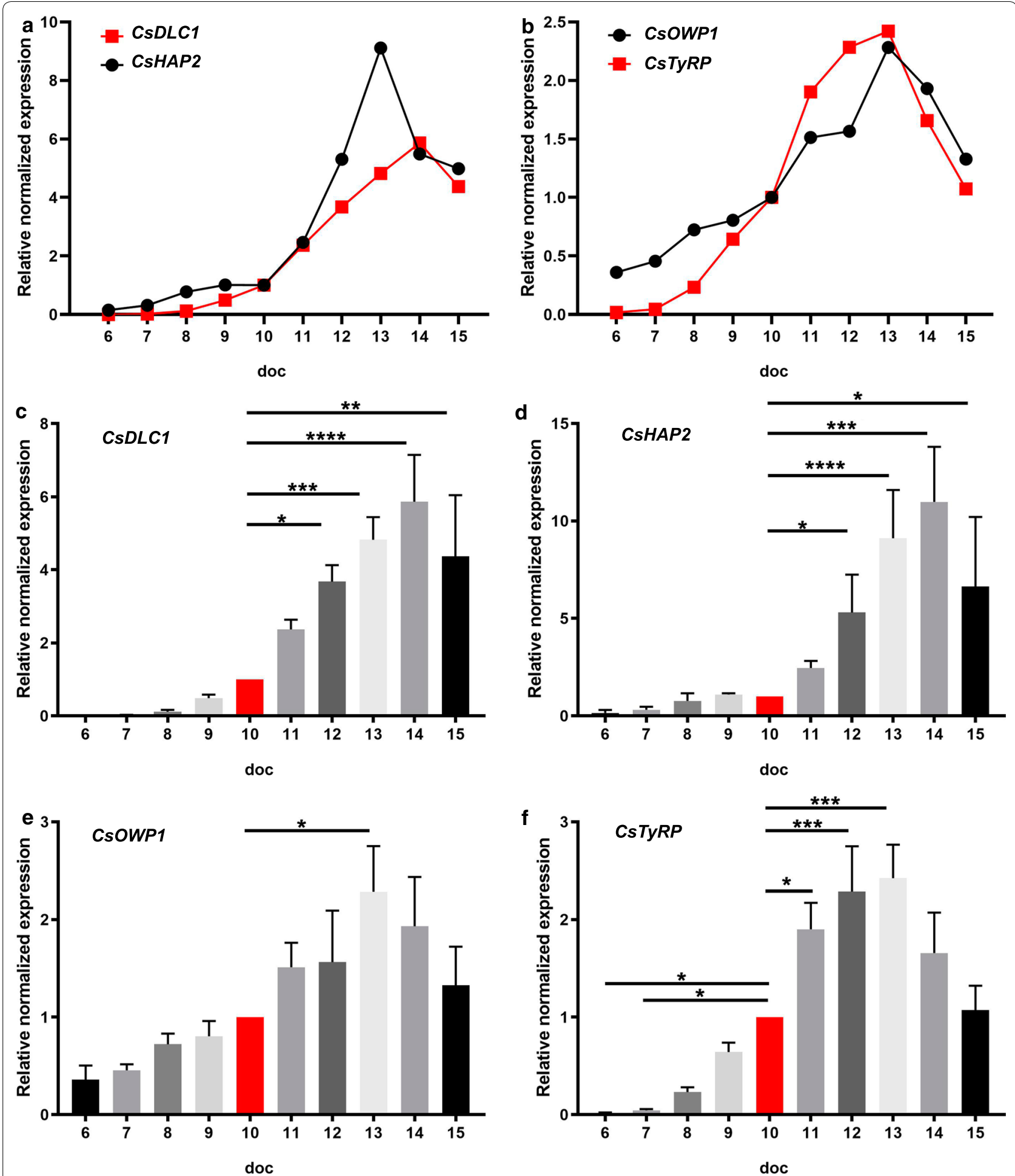

Fig. 6 Relative mRNA expression levels of sexual related genes in intracellular parasites. qRT-PCR of intracellular parasites from day 6 to day 15 of cultivation. a Microgamete-related genes. b Macrogamete-related genes. c CSDLC1. d CSHAP2. e CSOWP1. f CsTyRP (CSUI_001473). Values represent the mean \pm standard error (SE) from four independent experiments and are expressed as arbitrary absorbance units $(n=4)$. ${ }^{*} P<0.05,{ }^{* *} P<0.01 * * *$, $P<0.001,{ }^{* * *} P<0.0001$. For details on statistical tests (one-way ANOVA with multiple comparisons) see Additional file 2: Table S1 

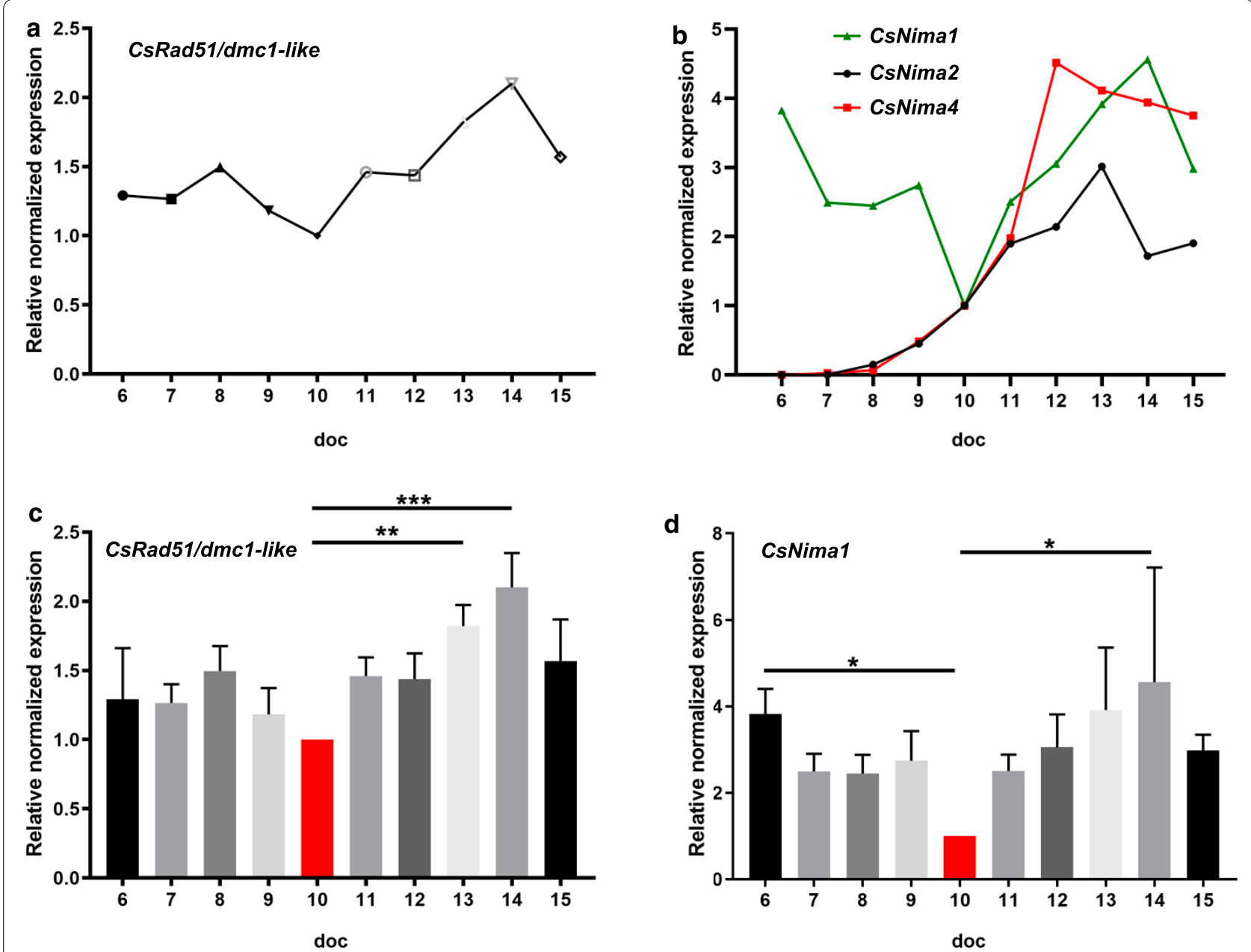

e
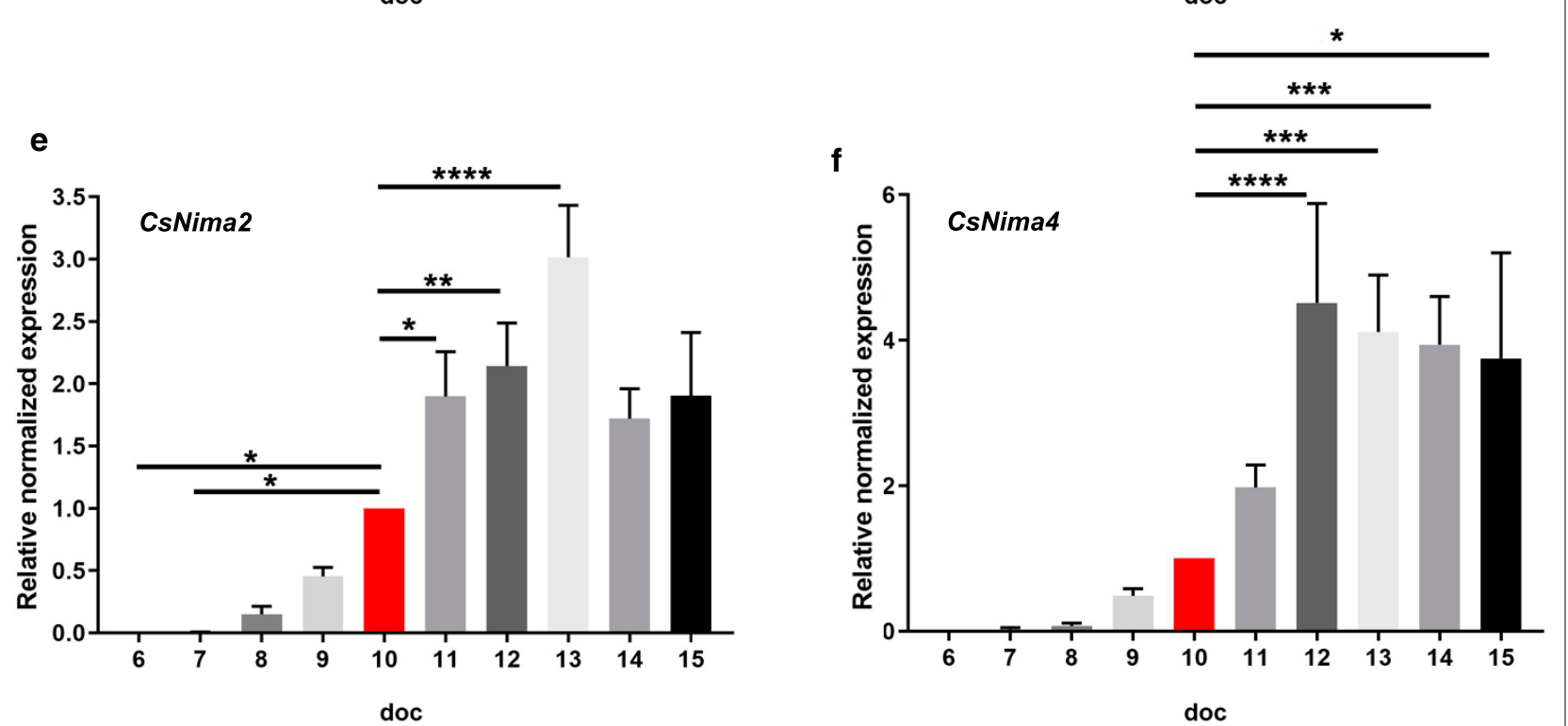

Fig. 7 Relative mRNA expression levels of related to cellular division and meiosis genes in intracellular parasites. qRT-PCR of intracellular parasites from 6 to 15 days of cultivation (doc). a CsRad51-related gene. b Nima-Nek-related kinase genes. c CsRad51. d CsNima1. e CsNima2.f CsNima4. Values represent the mean \pm standard error (SE) from four independent experiments and are expressed as arbitrary absorbance units $(n=4)$. ${ }^{*} P<0.05$, ${ }^{* *} P<0.01^{* *}, P<0.001,{ }^{* * *} P<0.0001$. For details on statistical tests (one-way ANOVA with multiple comparisons) see Additional file 2: Table S1 
budding and faithful segregation of genetic material. A point mutation in a conserved portion of the gene causes a severe mitotic defect [48]. In Plasmodium, Nima1 is found in replicative forms of the parasites, in asexual and sexual stages, with a role in mitosis, and specifically in microgametes. In extracellular parasites, Nima1 showed almost double the expression levels in gamonts compared to parasites at 6 doc, and Nima 2 and Nima 4 were almost exclusively transcribed in gamonts/gametes (Fig. 5b). The mRNA levels in intracellular parasites found for Nima1 were significantly higher on 6 and 14 doc compared to 10 doc (Fig. 7 b, d). Our results correlate with the presence of Nima1 in asexual stages and sexual stages [49]. Due to the simultaneous presence of both in cell culture an upregulation in sexual stages could not be observed. By contrast, Nima2 and Nima4 were practically absent before 9 doc when the first mature gamonts occurred and peaked at 13 and 14 doc, respectively (Fig. $7 \mathrm{~b}, \mathrm{e}, \mathrm{f}$ ). In Plasmodium, Nima2 and Nima4 are only found in female gametocytes and the two encoded proteins are necessary for completion of the sexual cycle. In Nek2 knockout parasites premeiotic DNA replication is dysregulated and the parasites do not develop ookinetes, suggesting that the principle role of Nek2 is during DNA replication preceding the meiosis Nek 4 does not appear to be required for gametocytogenesis but is essential for premeiotic DNA replication in the zygote, consistent with the cell cycle related function [55]. As these two Nima genes were expressed in parallel with the occurrence of gamonts and unsporulated oocysts in vitro we assume that the encoded proteins have similar roles during the development of $C$. suis.

\section{Conclusions}

Although sexual stages of Coccidia have previously been addressed for intervention in T. gondii infections, the lack of models for detailed studies on the involved stages in vitro has been highly prohibitive for more detailed research. In the present study, we could demonstrate mature gamonts, gametes and oocysts of $C$. suis in vitro in a defined time frame as well as a correlation of size and form of stages in vitro with those found in vivo. We also identified genes linked to the developmental and cell cycle progression of $C$. suis in vitro. We defined the demonstration of sexual stages in vitro, their time-limited occurrence and the gene expression of stage-specific genes. It was previously demonstrated in other coccidians, Eimeria and Toxoplasma, that interfering with fertilisation can block transmission of this parasite, providing a novel tool for intervention strategies and a hint at a potential developmental bottleneck in the life-cycle of $C$. suis.

\section{Supplementary information}

Supplementary information accompanies this paper at https://doi. org/10.1186/s13071-020-04014-4.

Additional file 1. Video of free microgametes, a macrogamont containing motile microgametes and a macrogamete in close proximity to each other, in real time.

Additional file 2: Table S1. Reporting of significant results from statistical analyses from Figs. 4, 5, 6, 7.

\begin{abstract}
Abbreviations
BLAST: basic local alignment search tool; DLC1: dynein light chain type 1 protein; GAM: sexual (macrogamete/macrogametocyte) stage proteins (wall-forming proteins, wfp); HAP2: male gamete fusion factor hapless-2; IPEC: intestinal porcine epithelial cells; Nima: "never in mitosis-A"-related kinases; Nek/NRK: Nima-related kinases; OWP1: oocyst wall protein 1; qRT-PCR: quantitative real time polymerase chain reaction; Rad51: DNA repair protein 51; TyRP: tyrosine rich protein.
\end{abstract}

\section{Acknowledgements}

We would like to thank the animal technicians Sonja Rohrer and Martina Lastufka for taking care of the piglets used for oocyst collection for this study, as well as the Core Facility Cell Imaging and Ultrastructure Research, University of Vienna-member of the Vienna Life-Science Instruments (VLSI) and especially Mag. Daniela Gruber for her expertise in all performed scanning electron microscopy work.

\section{Authors' contributions}

AJ designed the study. BR provided oocysts, sporozoites and merozoites and was responsible for the maintenance of the cell culture. ASF isolated and prepared the stages from in vitro cultures and performed all morphological analyses. TCB processed and analyzed all genetic experiments. ASF and TCB drafted the manuscript. All authors read and approved the final manuscript.

\section{Funding}

ASF is funded through the Graduate School "Pig and Poultry Medicine" of the University of Veterinary Medicine Vienna.

\section{Availability of data and materials}

All data and materials of the experiments described here are included in this published article and its additional files.

\section{Ethics approval and consent to participate}

All procedures in this study involving experimental animals were approved by the Austrian Federal Ministry of Science and the Ethics Committee of the University of Veterinary Medicine Vienna in strict accordance with the Austrian Animal Protection law (BMWF-68.204/0059-V/3b/2018). All efforts were made to minimize the number of animals used for $C$. suis oocyst generation.

\section{Consent for publication}

Not applicable.

\section{Competing interests}

The authors declare that they have no competing interests.

Received: 19 December 2019 Accepted: 10 March 2020

Published online: 18 March 2020

\section{References}

1. Martineau GP, Del Castillo J. Epidemiological, clinical and control investigations on field porcine coccidiosis: clinical, epidemiological and parasitological paradigms? Parasitol Res. 2000;86:834-7.

2. Stuart BP, Lindsay DS. Coccidiosis in swine. Vet Hum Toxicol. 1987;29:65-7.

3. Stuart BP, Lindsay DS, Ernst JV, Gosser HS. Isospora suis enteritis in piglets. Vet Pathol. 1980;17:84-93. 
4. Joachim A, Shrestha A. Coccidiosis of pigs. In: Dubey JP, editor. Coccidiosis in livestock, companion animals and humans. Boca Raton: CRC Press; 2020. p. 125-45.

5. Lindsay DS, Stuart BP, Wheat BE, Ernst JV. Endogenous development of the swine coccidium, Isospora suis Biester 1934. J Parasitol. 1980;66:771-9.

6. Lindsay DS, Quick DP, Steger AM, Toivio-Kinnucan MA, Blagburn BL. Complete development of the porcine coccidium Isospora suis Biester, 1934 in cell cultures. J Parasitol. 1998;84:635.

7. Worliczek HL, Ruttkowski B, Schwarz L, Witter K, Tschulenk W, Joachim A. Isospora suis in an epithelial cell culture system -an in vitro model for sexual development in coccidia. PLoS One. 2013;8:e69797.

8. Smith TG, Walliker D, Ranford-Cartwright LC. Sexual differentiation and sex determination in the Apicomplexa. Trends Parasitol. 2002;1 8:315-23.

9. Mai K, Sharman PA, Walker RA, Katrib M, Souza DDE, McConville MJ, et al. Oocyst wall formation and composition in coccidian parasites. Mem Inst Oswaldo Cruz. 2009;104:281-9.

10. Mouafo A, Weck-Heimann A, Dubremetz JF, Entzeroth R. Monoclonal antibodies specific for the two types of wall-forming bodies of Eimeria tenella macrogametes (Coccidia, Apicomplexa). Parasitol Res. 2002;88:217-24.

11. Su S, Hou Z, Liu D, Jia C, Wang L, Xu J, et al. Comparative transcriptome analysis of Eimeria necatrix third-generation merozoites and gametocytes reveals genes involved in sexual differentiation and gametocyte development. Vet Parasitol. 2018;252:35-46.

12. Possenti A, Fratini F, Fantozzi L, Pozio E, Dubey JP, Ponzi M, et al. Global proteomic analysis of the oocyst/sporozoite of Toxoplasma gondii reveals commitment to a host-independent lifestyle. BMC Genomics. 2013;14:183.

13. Wallach MG, Mencher D, Yarus S, Pillemer G, Halabi A, Pugatsch T. Eimeria maxima: identification of gametocyte protein antigens. Exp Parasitol. 1989;68:49-56.

14. Spano F, Puri C, Ranucci L, Putignani L, Crisanti A. Cloning of the entire COWP gene of Cryptosporidium parvum and ultrastructural localization of the protein during sexual parasite development. Parasitology. 1997;114:427-37.

15. Lippuner C, Ramakrishnan C, Basso WU, Schmid MW, Okoniewski M, Smith NC, et al. RNA-Seq analysis during the life cycle of Cryptosporidium parvum reveals significant differential gene expression between proliferating stages in the intestine and infectious sporozoites. Int J Parasitol. 2018;48:413-22.

16. Belli SI, Wallach MG, Luxford C, Davies MJ, Smith NC. Roles of tyrosine-rich precursor glycoproteins and dityrosine- and 3,4-dihydroxyphenylalaninemediated protein cross-linking in development of the oocyst wall in the coccidian parasite Eimeria maxima. Eukaryot Cell. 2003;2:456-64.

17. Walker RA, Ferguson DJP, Miller CMD, Smith NC. Sex and Eimeria: a molecular perspective. Parasitology. 2013;140:1701-17.

18. Xu J, Zhang Y, Tao J. Efficacy of a DNA vaccine carrying Eimeria maxima Gam56 antigen gene against coccidiosis in chickens. Korean J Parasitol. 2013;51:147-54.

19. Jang SI, Lillehoj HS, Lee SH, Lee KW, Park MS, Cha SR, et al. Eimeria maxima recombinant Gam82 gametocyte antigen vaccine protects against coccidiosis and augments humoral and cell-mediated immunity. Vaccine. 2010;28:2980-5.

20. Rafiqi SI, Garg R, Ram H, Reena KK, Asari M, Kumari P, et al. Immunoprophylactic evaluation of recombinant gametocyte 22 antigen of Eimeria tenella in broiler chickens. Parasitol Res. 2019;1 18:945-53.

21. Possenti A, Cherchi S, Bertuccini L, Pozio E, Dubey JP, Spano F. Molecular characterisation of a novel family of cysteine-rich proteins of Toxoplasma gondii and ultrastructural evidence of oocyst wall localisation. Int J Parasitol. 2010;40:1639-49.

22. Templeton TJ, Lancto CA, Vigdorovich V, Liu C, London NR, Hadsall KZ, et al. The Cryptosporidium oocyst wall protein is a member of a multigene family and has a homolog in Toxoplasma. Infect Immun. 2004;72:980-7.

23. Briggs $L J$, Davidge JA, Wickstead B, Ginger ML, Gull K. More than one way to build a flagellum: comparative genomics of parasitic protozoa. Curr Biol. 2004;14:611-2.

24. Khan SM, Franke-Fayard B, Mair GR, Lasonder E, Janse CJ, Mann M, et al. Proteome analysis of separated male and female gametocytes reveals novel sex-specific Plasmodium biology. Cell. 2005;121:675-87.

25. Ferguson DJP, Sahoo N, Pinches RA, Bumstead JM, Tomley FM, Gubbels M-J. MORN1 has a conserved role in asexual and sexual development across the apicomplexa. Eukaryot Cell. 2008;7:698-711.
26. Fédry J, Liu Y, Péhau-Arnaudet G, Pei J, Li W, Tortorici MA, et al. The ancient gamete fusogen HAP2 is a eukaryotic class II fusion protein. Cell. 2017;168:904-15.

27. Walker RA, Sharman PA, Miller CM, Lippuner C, Okoniewski M, Eichenberger RM, et al. RNA Seq analysis of the Eimeria tenella gametocyte transcriptome reveals clues about the molecular basis for sexual reproduction and oocyst biogenesis. BMC Genomics. 2015;16:94.

28. Angrisano F, Sala KA, Da DF, Liu Y, Pei J, Grishin NV, et al. Targeting the conserved fusion loop of HAP2 inhibits the transmission of Plasmodium berghei and falciparum. Cell Rep. 2017;21:2868-78.

29. Ramakrishnan C, Maier S, Walker RA, Rehrauer H, Joekel DE, Winiger RR, et al. An experimental genetically attenuated live vaccine to prevent transmission of Toxoplasma gondii by cats. Sci Rep. 2019;9:1474.

30. Weedall GD, Hall N. Sexual reproduction and genetic exchange in parasitic protists. Parasitology. 2015;142(Suppl. 1):120-7.

31. Fritz HM, Bowyer PW, Bogyo M, Conrad PA, Boothroyd JC. Proteomic analysis of fractionated Toxoplasma oocysts reveals clues to their environmental resistance. PLoS One. 2012;7:e29955.

32. Carvalho TG, Doerig C, Reininger L. Nima- and Aurora-related kinases of malaria parasites. Biochim Biophys Acta. 2013;1834:1336-45.

33. Gonzalez-Vallina R, Wang H, Zhan R, Berschneider HM, Lee RM, Davidson NO, et al. Lipoprotein and apolipoprotein secretion by a newborn piglet intestinal cell line (IPEC-1). Am J Physiol. 1996;271:249-59.

34. Diesing AK, Nossol C, Panther P, Walk N, Post A, Kluess J, et al. Mycotoxin deoxynivalenol (DON) mediates biphasic cellular response in intestinal porcine epithelial cell lines IPEC-1 and IPEC-J2. Toxicol Lett. 2011;200:8-18.

35. Schierack P, Nordhoff M, Pollmann M, Weyrauch KD, Amasheh S, Lodemann U, et al. Characterization of a porcine intestinal epithelial cell line for in vitro studies of microbial pathogenesis in swine. Histochem Cell Biol. 2006;125:293-305.

36. Matuschka F, Heydorn AO. Die Entwicklung von Isospora suis Biester und Murray 1934 (Sporozoa:Coccidia:Eimeriidae) im Schwein. 1980;26:405-76.

37. Madden PA, Vetterling JM. Scanning electron microscopy of Eimeria tenella microgametogenesis and fertilization. J Parasitol. 1977;63:607-10.

38. Scholtyseck E, Mehlhorn H, Hammond DM. Electron microscope studies of microgametogenesis in coccidia and related groups. Zeitschrift für Parasitenkd. 1972;38:95-131.

39. Matos LVS, MCEvoy J, Tzipori S, Bresciani KDS, Widmer G. The transcriptome of Cryptosporidium oocysts and intracellular stages. Sci Rep. 2019;9:7856.

40. Fritz HM, Buchholz KR, Chen X, Durbin-Johnson B, Rocke DM, Conrad PA, et al. Transcriptomic analysis of Toxoplasma development reveals many novel functions and structures specific to sporozoites and oocysts. PLoS One. 2012;7:e29998.

41. Su S, Hou Z, Liu D, Jia C, Wang L, Xu J, et al. Comparative transcriptome analysis of second-and third-generation merozoites of Eimeria necatrix. Parasit Vectors. 2017;10:388.

42. Wass MN, Stanway R, Blagborough AM, Lal K, Prieto JH, Raine D, et al. Proteomic analysis of Plasmodium in the mosquito: progress and pitfalls. Parasitology. 2012;139:1131-45.

43. Morahan B, Garcia-Bustos J. Kinase signalling in Plasmodium sexual stages and interventions to stop malaria transmission. Mol Biochem Parasitol. 2014;193:23-32.

44. Shrestha A, Palmieri N, Abd-Elfattah A, Ruttkowski B, Pagès $M$, Joachim A. Cloning, expression and molecular characterization of a Cystoisospora suis specific uncharacterized merozoite protein. Parasit Vectors. 2017;10:68.

45. Morrissette N. Targeting Toxoplasma tubules: tubulin, microtubules, and associated proteins in a human pathogen. Eukaryot Cell. 2015;14:2-12.

46. Qureshi BM, Hofmann NE, Arroyo-Olarte RD, Nickl B, Hoehne W, Jungblut PR, et al. Dynein light chain 8a of Toxoplasma gondii, a unique conoidlocalized $\beta$-strand-swapped homodimer, is required for an efficient parasite growth. FASEB J. 2012;27:1034-47.

47. Wong JL, Johnson MA. Is HAP2-GCS1 an ancestral gamete fusogen? Trends Cell Biol. 2010;20:134-41.

48. Hussein HE, Bastos RG, Schneider DA, Johnson WC, Adham FK, Davis WC, et al. The Babesia bovis hap2 gene is not required for blood stage replication, but expressed upon in vitro sexual stage induction. PLoS Negl Trop Dis. 2017;11:e0005965.

49. Jonscher E, Erdbeer A, Günther M, Kurth M. Two COWP-like cysteine rich proteins from Eimeria nieschulzi (coccidia, apicomplexa) are expressed 
during sporulation and involved in the sporocyst wall formation. Parasit Vectors. 2015;8:395.

50. Belli SI, Smith NC, Ferguson DJP. The coccidian oocyst: a tough nut to crack! Trends Parasitol. 2006;22:416-23.

51. Wallach M. Role of antibody in immunity and control of chicken coccidiosis. Trends Parasitol. 2010;26:382-7.

52. Joachim A, Ruttkowski B, Sperling D. Detection of Cystoisospora suis in faeces of suckling piglets-when and how? A comparison of methods. Porc Heal Manag. 2018:4:20

53. Brown MS, Grubb J, Zhang A, Rust MJ, Bishop DK. Small Rad51 and Dmc1 complexes often co-occupy both ends of a meiotic DNA double strand break. PLoS Genet. 2015;11:e1005653.
54. Reininger L, Garcia M, Tomlins A, Müller S, Doerig C. The Plasmodium falciparum, Nima-related kinase Pfnek-4: a marker for asexual parasites committed to sexual differentiation. Malar J. 2012;11:250.

55. Reininger L, Tewari R, Fennell C, Holland Z, Goldring D, Ranford-Cartwright $L$, et al. An essential role for the Plasmodium Nek-2 Nima-related protein kinase in the sexual development of malaria parasites. J Biol Chem. 2009;284:20858-68.

\section{Publisher's Note}

Springer Nature remains neutral with regard to jurisdictional claims in published maps and institutional affiliations.
Ready to submit your research? Choose BMC and benefit from:

- fast, convenient online submission

- thorough peer review by experienced researchers in your field

- rapid publication on acceptance

- support for research data, including large and complex data types

- gold Open Access which fosters wider collaboration and increased citations

- maximum visibility for your research: over $100 \mathrm{M}$ website views per year

At BMC, research is always in progress.

Learn more biomedcentral.com/submissions 